\title{
Antitumoral, Antileishmanial and Antimalarial Activity of Pentacyclic 1,4-Naphthoquinone Derivatives
}

\author{
Alcides J.M. da Silva, ${ }^{*, a}$ Chaquip D. Netto, ${ }^{a}$ Wallace Pacienza-Lima,${ }^{b}$ Eduardo Caio Torres-Santos,,${ }^{b, c}$ \\ Bartira Rossi-Bergmann, ${ }^{b}$ Severine Maurel, ${ }^{d}$ Alexis Valentin ${ }^{d}$ and Paulo R.R. Costa ${ }^{*, a}$
${ }^{a}$ Laboratório de Química Bioorgânica, Núcleo de Pesquisas de Produtos Naturais; Centro de Ciências da Saúde, Bloco H, Universidade Federal do Rio de Janeiro-RJ 21941-590, Brazil
${ }^{b}$ Instituto de Biofísica Carlos Chagas Filho; Centro de Ciências da Saúde, Bloco G, Universidade Federal do Rio de Janeiro, Rio de Janeiro-RJ 21941-590, Brazil

'Laboratório de Bioquímica de Tripanosomatídeos, Instituto Oswaldo Cruz, Rio de Janeiro-RJ 21045-900, Brazil

${ }^{d}$ UMR 152, IRD Université Paul Sabatier, Pharmacochimie des Substances Naturelles et Pharmacophores Redox. Faculté de Pharmacie, 118 route de Narbonne, F-31062 Toulouse Cedex 4, France

\begin{abstract}
As pterocarpanquinonas 8a-c, previamente sintetizadas em nosso laboratório, e uma série homóloga de derivados, substâncias 9a-c preparadas neste trabalho, foram avaliadas em células de câncer de mama (MCF-7) e em cultura dos parasitas Leishmania amazonensis e Plasmodium falciparum. As substâncias 8a-c foram mais potentes que 9a-c nas células tumorais e em Leishmania amazonensis. Por outro lado, 9a-c mostraram ser as mais ativas sobre o Plasmodium falciparum. Todas as substâncias estudadas foram biosseletivas, apresentando baixa citotoxicidade para linfócitos murinos frescos e linfócitos humanos ativados pelo mitógeno fitoemoaglutinina (PHA).

Pterocarpanquinones 8a-c, previously synthesized in our laboratory, and an homologous series of derivatives, compounds 9a-c prepared in this work, were evaluated on breast cancer cells (MCF-7) and on the parasites Leishmania amazonensis and Plasmodium falciparum, in culture. Compounds 8a-c were more potent than 9a-c on tumor cells and Leishmania amazonensis. On the other hand, 9a-c showed to be more active on Plasmodium falciparum. All the compounds studied were bioselective, presenting negligible cytotoxicity against fresh murine lymphocytes and human lymphocytes activated by the mitogen phytohemaglutinin (PHA).
\end{abstract}

Keywords: antineoplasic, antiparasitic, pterocarpans, naphtoquinones, oxa-Heck reaction, antimalarial, leishmanicide

\section{Introduction}

Phytoalexins or phytotoxins are low molecular substances produced by plants in response to microorganism attacks. ${ }^{1}$ These compounds inhibit the growth of bacteria and fungi in vivo and in vitro, and their production during an infection can induce resistance to subsequent infections. It has been shown that pterocarpans, among other group of natural products, act as phytoalexins. Phaseollidin for example (1, Figure 1), is present in higher concentration in species of Colombian beans resistant to Colletotrichum lindemuthianum fungus, the causal agent

*e-mail: lqb@nppn.ufrj.br of anthrachnose disease, than in species sensitive to this fungus. ${ }^{1}$ Pterocarpans present other interesting biological properties, depending on the pattern of substitution present at the A- and D-rings (Figure 1). For example, edunol (2), isolated from Harpalyce braziliana, a plant used in the northeast of Brazil as folk medicine, shows antiofidic activity in vitro and in vivo (mices). ${ }^{2}$ Pterocarpan $\mathbf{3}$, isolated from a plant of genus Erythrina, presents anti-HIV activity in vitro ${ }^{3}$ and crotafuran B (4), isolated from Crotalaria pallida, has antiinflamatory properties in vitro. ${ }^{4}$ In 1995 , the catechol pterocarpan $\mathbf{5}$ was isolated from Petalostemon purpureus and showed to be active on $\mathrm{KB}$ cells, a human epidermoid carcinoma cell line. ${ }^{5}$ This compound and four new derivatives were synthesized and their toxicities in 
leukemia cell lines, including cell lines with MDR (multi drug resistant) phenotype were evaluated. ${ }^{6}$ Cathecol $\mathbf{5}$ and its possible metabolite in vivo, ortho-quinone $\mathbf{6}$, showed to be the most active compounds. While $\mathbf{5}$ was bioselective, 6 presented high toxicity against human lymphocytes activated by the mitogen phytohemaglutinin (PHA).
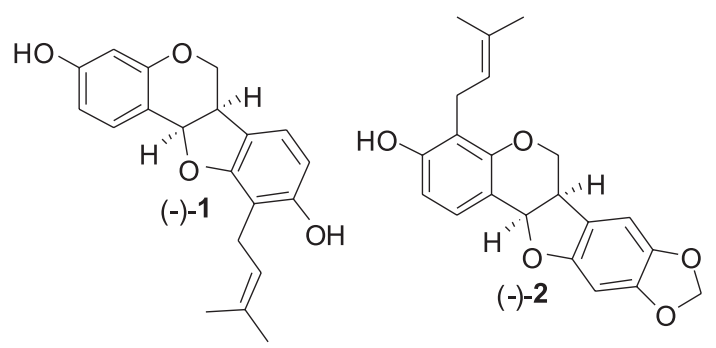<smiles>COc1cc2c(cc1CC=C(C)C)[C@H]1O[C@H]3c4ccc(O)cc4[C@H]3CO[C@@H]21</smiles>
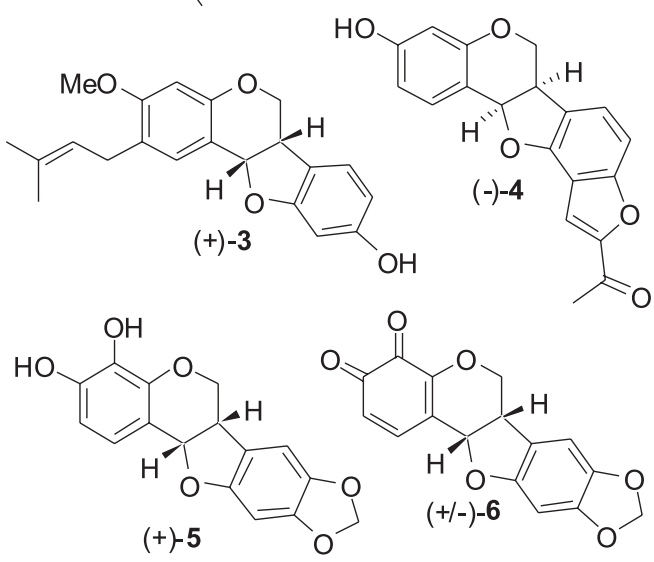

Figure 1. Bioactive naturally occurring pterocarpans (1-5) and derivative (6).

It is known that ortho-quinones lead to a depletion of physiological levels of $\mathrm{NAD}(\mathrm{P}) \mathrm{H}$ and mitochondrial membrane depolarization and react with DNA, leading to depurinating adducts. ${ }^{7}$ This transformation has proven relevant in the toxicity of some hormones and steroids which are metabolized to ortho-quinones. ${ }^{7}$ Thus we find most promising the design and synthesis of para-quinones derivatives, due to its lower toxicity and pterocarpanquinones 8a-c (Figure 2) were chosen as new prototype molecules. ${ }^{8}$ The new molecular architecture present in the structure of these compounds was designed through molecular hydridization between lapachol (7a) and $\alpha$-lapachone (7b), two antineoplasic 1,4-naphthoquinones isolated from Tabebuia species $^{9}$ and pterocarpan 5 (Figure 1), which as mentioned before, is cytotoxic for KB and leukemia cells in culture (Figure 2). ${ }^{5,6}$ The interesting pharmacological results obtained for 8a-c prompted us to prepare an homologous series, compounds $\mathbf{9 a - c}$ (Figure 2). Although the same groups are present at E-ring in compounds 8a-c and 9a-c, molecular modelling studies ( $a b$ initio) showed that the presence of the additional methylene group at the D-ring in 9a-c alters the molecular

shape. ${ }^{10}$ In this paper we describe the preparation of the new homologous pterocarpanquinones 9a-c. The effect of compounds 8a-c and 9a-c on MCF-7 cells (breast cancer),${ }^{11}$ cultured Plasmodium falciparum ${ }^{12}$ and culture Leishmania brasiliensis ${ }^{13}$ are compared, providing interesting information on the structural features required for bioactivity and bioselectivity.<smiles>CC(C)=CCC1=C(O)C(=O)c2ccccc2C1=O</smiles>

$7 a$

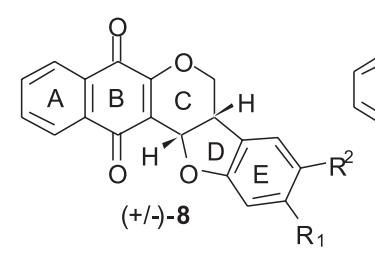

a, $\mathrm{R}^{1}-\mathrm{R}^{2}=-\mathrm{OCH}_{2} \mathrm{O}-; \mathbf{b}, \mathrm{R}^{1}=\mathrm{OMe}, \mathrm{R}^{2}=\mathrm{OH} ; \mathbf{c}, \mathrm{R}^{1}=\mathrm{OH}, \mathrm{R}^{2}=\mathrm{OMe}$

Figure 2. Lapachol 7a, $\alpha$-lapahone 7 and pterocarpanquinones studied in this work.

\section{Results and Discussion}

Several approaches are reported in the literature to prepare pterocarpans ${ }^{14}$ but the oxy-arylation of chromenes, described for the first time in 1976 by Horino and co-workers, is the most used. ${ }^{8,15}$ The choice of this approach seems to be related with the easy preparation of oxygenated ortho-mercury phenols through electrophilic mercuration and the transformation of these products into the corresponding ortho-palladium phenols by mercurypalladium exchange at room temperature. These species react with chromenes through an oxa-Heck reaction, allowing the introduction of different oxygenated aromatic moieties present at $\mathrm{D}$-ring in the structure of pterocarpans. However, a severe limitation of this reaction is the use of organomercurials and $\mathrm{PdCl}_{2}$ in stoichiometric amounts.

Some years ago Larock and co-workers ${ }^{16}$ described a catalytic version for this reaction by using chromenes and dihydronaphthalen as olefins, and ortho-iodophenols instead ortho-mercury phenols, under conditions favoring the intervention of neutral palladium species $\left(\mathrm{Et}_{3} \mathrm{~N}, \mathrm{DMF}\right.$, $\left.\mathrm{Pd}(\mathrm{OAc})_{2}, n-\mathrm{Bu}{ }_{4} \mathrm{NCl}\right)$. Kiss and co-workers ${ }^{17}$ also reported the oxy-arylation of 7-(benzyloxy)- $2 \mathrm{H}$-chromene by ortho-iodophenol under conditions favoring a cationic mechanism $\left(\mathrm{Ag}_{2} \mathrm{CO}_{3}\right.$, acetone, $\left.\mathrm{PPh}_{3}, \mathrm{Pd}(\mathrm{OAc})_{2}\right)$, but the scope of this reaction was not investigated by studying additional examples. In contrast with the easy preparation of oxygenated ortho-mercury phenols, oxygenated 
ortho-iodo phenols are more difficult to obtain and only few examples describing the iodination of these very reactive substrates are reported in the literature ${ }^{18}$ and, maybe for this reason, until this moment natural products were not prepared by using Larock's and Kiss' approaches.

In view of the difficulty to prepare oxygenated ortho-iodophenols, ${ }^{18}$ pterocarpanquinones 8 a-c were previously synthesized in our laboratory ${ }^{8}$ through an oxa-Heck reaction between chromenequinone $\mathbf{1 0}$ and ortho-mercury phenols 11a-c, under the original Horino's conditions $^{15}$ (Scheme 1). This is the sole report on the use of an electron poor chromene in an oxa-Heck reaction. While we are studying conditions to accomplish these reactions from ortho-iodo phenols in the presence of catalytic amounts of Pd reagents, ${ }^{19}$ we decided to study the synthesis of pterocarpanquinones 9a-c under the Horino's conditions, using ortho-mercury benzyl alcohols 12a-c instead ortho-mercury phenols 11a-c as source of organic species of palladium in this new oxy-arylation reaction (Scheme 1).

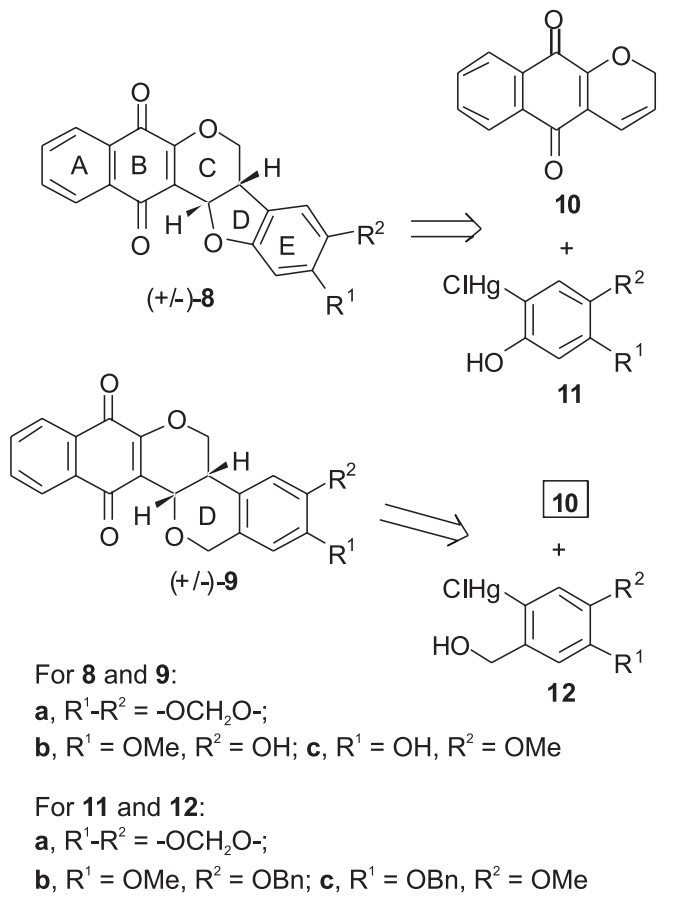

Scheme 1. Previous synthesis of 8a-c and proposed synthesis of 9a-c using Horino's protocol.

ortho-Mercury benzyl alcohols (12a-c) were prepared from easily available aldehydes 13a-c, by reduction of the carbonyl group with $\mathrm{NaBH}_{4}$ followed by ortho-mercuration of the resulting alcohols $14 a-c$ with $\mathrm{Hg}(\mathrm{AcO})_{2} / \mathrm{LiCl}$ (Scheme 2). Reaction of chromene 10 with 12a-c in the presence of stoichiometric $\mathrm{PdCl}_{2}$ and $\mathrm{LiCl}$ in acetone at room temperature led to naphthoquinone $9 \mathrm{a}$ and $O$-benzylated derivatives 9d,e, respectively. Hydrogenolysis of the protecting benzyl groups in $\mathbf{9 d}$,e gave the naphthoquinones 9b,c. In an attempt to get a catalytic version for this reaction, we performed an unsuccessfull experiment seeking the coupling of chromene $\mathbf{1 0}$ with the ortho-iodo benzyl alcohol. ${ }^{19}$ This result has discouraged us to obtain ortho-iodo oxygenated benzylic alcohols.

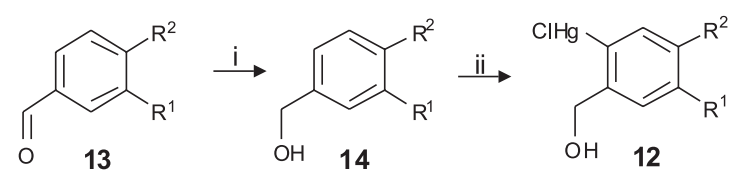

a, $99 \%$; b, $89 \%$; c, $90 \% \quad$ a, $65 \%$; b , $75 \%$; c, $100 \%$

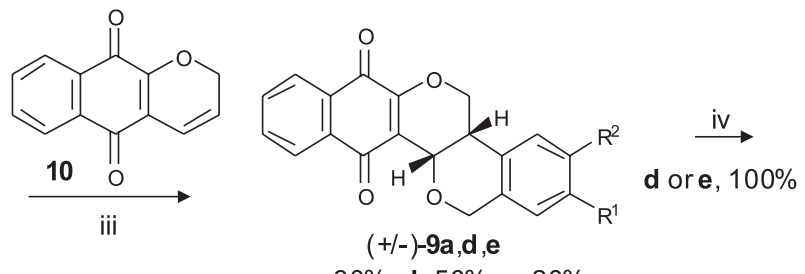

a, $30 \%$; d, $50 \%$; e, $20 \%$

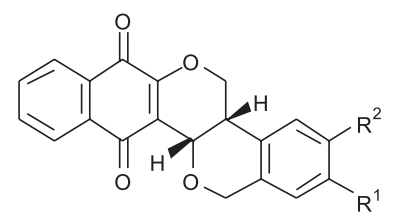

$(+/-)-9 b, c$

a, $\mathrm{R}^{1}-\mathrm{R}^{2}=-\mathrm{OCH}_{2} \mathrm{O}-$

b, $\mathrm{R}^{1}=\mathrm{OMe}, \mathrm{R}^{2}=\mathrm{OH}$

c, $\mathrm{R}^{1}=\mathrm{OH}, \mathrm{R}^{2}=\mathrm{OMe}$

d, $R^{1}=O M e, R^{2}=O B n$

e, $R^{1}=O B n, R^{2}=O M e$

i, $\mathrm{NaBH}_{4}\left(1.25\right.$ eq), $\mathrm{HCl}(10 \%), \mathrm{MeOH}, 0{ }^{\circ} \mathrm{C}, 4 \mathrm{~h}$; ii, $(\mathrm{AcO})_{2} \mathrm{Hg}(3 \mathrm{eq}), \mathrm{LiCl}$ ( 3 eq), $\mathrm{MeOH}, 7$ days; iii, $\mathrm{PdCl}_{2}, \mathrm{LiCl}$, acetone, iv $\mathrm{H}_{2}, \mathrm{Pd} / \mathrm{C}$, acetone.

Scheme 2. Synthesis of pterocarpanquinones 9a-c.

Our next goal was to check the relative stereochemistry in 9a-c (Figure 2). Due to the overlapping of chemical shifts, nOe experiments involving hydrogens $\mathrm{H} 4 \mathrm{~b}$ and $\mathrm{H} 12 \mathrm{~b}$ could not be accomplished and we tried to establish the stereochemistry based on coupling constants. The dihedral angles calculated by molecular modelling ${ }^{10}$ for hydrogens $\mathrm{H} 4 \mathrm{~b}$ and $\mathrm{H} 12 \mathrm{~b}$ in 9a and the hypothetical corresponding trans-isomer 15 are $48.63^{\circ}$ and $173.58^{\circ}$ respectively, and the expected values for coupling constant between these hydrogens are $3.04 \mathrm{~Hz}$ and $10.16 \mathrm{~Hz}$, respectively. ${ }^{20}$ Once the observed coupling constant was $2.93 \mathrm{~Hz}$, these data strongly suggest a cis-geometry around $\mathrm{C}$ and D-rings, in 9a (Figure 3). The same trend in $J \mathrm{H} 4 \mathrm{~b}, \mathrm{H} 12 \mathrm{~b}$ was observed for compounds 9b-e. Recently, cis-coumarin-annulated sulfur heterocycles were described and the proposed cis-configuration between six-membered rings $\mathrm{B}$ and $\mathrm{C}$ was determined by ${ }^{1} \mathrm{H}$ NMR $(J=4.0 \mathrm{~Hz}){ }^{21}$

\section{Pharmacology}

The antitumoral effect on MCF-7 cells (breast cancer), antileishmanial effect on cultured Leishmania 


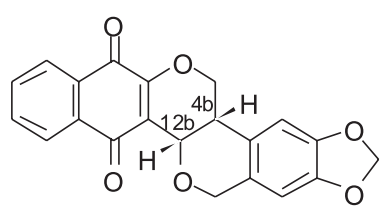

$(+/-)-9 a$

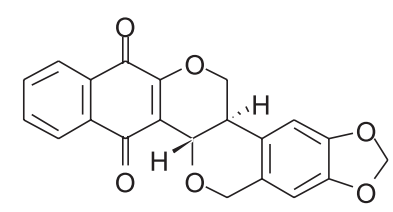

$(+/-)-15$ dihedral angle between $\mathrm{H} 4 \mathrm{~b} / \mathrm{C} 4 \mathrm{~b} / \mathrm{C} 12 \mathrm{~b}$ and $\mathrm{H} 12 \mathrm{~b} / \mathrm{C} 12 \mathrm{~b} / \mathrm{C} 4 \mathrm{~b}$

$$
\begin{array}{lrl}
(+/-)-9 \mathbf{a} & 48.63^{\circ} & J=3.04 \mathrm{~Hz} \quad J=2.93 \mathrm{~Hz} \\
(+/-)-15 & 173.58^{\circ} & J=10.16 \mathrm{~Hz}
\end{array}
$$

Figure 3. Epimeric pterocarpanquinones $\mathbf{9 a}$ and $\mathbf{1 5}$.

amazonensis promastigotes and antimalarial effect on cultured Plasmodium falciparum (FcB1 strain, resistant to chloroquine) are shown in Table 1. Naphthoquinone 8a, bearing the apolar methylenedioxy group at the E-ring, was the least active in inhibiting the proliferation of MCF-7 cells $\left(\mathrm{IC}_{50}=29.3 \mu \mathrm{mol} \mathrm{L}{ }^{-1}\right)$. In contrast, the presence of the hydroxyl group in $\mathbf{8 b}$ and $\mathbf{8 c}$ increased the antitumoral potency by approximately four-fold $\left(\mathrm{IC}_{50}=5.3\right.$ and $7.8 \mu \mathrm{mol} \mathrm{L}^{-1}$, respectively). Similar to series $\mathbf{8}$, in series 9 compound 9a was also the least active on MCF-7 cells $\left(\mathrm{IC}_{50}=19.3 \mu \mathrm{mol} \mathrm{L}{ }^{-1}\right)$. Likewise, the presence of hydroxyl groups in E-ring also increased the antitumoral potency in ca. 2 -fold $\left(\mathrm{IC}_{50}=12.5 \mu \mathrm{mol} \mathrm{L} \mathrm{L}^{-1}\right.$ for $9 \mathrm{~b}$ and $8.5 \mu \mathrm{mol} \mathrm{L}-1$ for $9 c$ ).

The antileishmanial activity of the series $\mathbf{8}$ compounds was also modulated by the pattern of substitution at the E-ring. The presence of free phenol groups in ring $\mathrm{E}$ in compounds $\mathbf{8 b}$ and $\mathbf{8 c}$ greatly increased the molecule activity $\left(\mathrm{IC}_{50}=1.67\right.$ and $1.96 \mu \mathrm{mol} \mathrm{\textrm {L } ^ { - 1 }}$ respectively) as compared to $8 \mathbf{a}\left(\mathrm{IC}_{50}=9.60 \mu \mathrm{mol} \mathrm{L}-1\right)$. The ring expansion from 5 to 6 members in 9 substantially reduced the antileishmanial activity $\left(\mathrm{IC}_{50}>20.0,11.7\right.$ and $6.8 \mu \mathrm{mol} \mathrm{L}{ }^{-1}$ for $9 \mathbf{a}, 9 \mathbf{b}$ and $9 \mathbf{c}$, respectively).

Similarly to the antileishmanial activity, naphthoquinone 8a was the least active of the series 8 compounds on Plasmodium falciparum $\left(\mathrm{IC}_{50}>\right.$ $10.0 \mu \mathrm{mol} \mathrm{L}^{-1}$ ), while the presence of free phenol groups at E-ring in $\mathbf{8 b}$ and $\mathbf{8 c}$ resulted in a five to ten fold increase in activity $\left(\mathrm{IC}_{50}=0.88\right.$ and $2.50 \mu \mathrm{mol} \mathrm{L}{ }^{-1}$, respectively). Contrary to observed with the antitumoral and antileishmanial activity, where the most potent compounds were of the series $\mathbf{8}$, the antimalarial activity of series $\mathbf{9}$ compounds were superior to series $\mathbf{8}$, effective in the sub-micromolar range $\left(\mathrm{IC}_{50}=0.28,0.03\right.$, and $0.04 \mu \mathrm{mol} \mathrm{L}^{-1}$ for $9 \mathbf{a}, \mathbf{9 b}$ and $\mathbf{9 c}$, respectively). These results suggest that the molecular target(s) of series 9 compounds on Plasmodium falciparum is probably distinct from Leishmania amazonensis and MCF-7 cells. Chloroquine, $\alpha$-lapachone (7) and amphotericin B were
Table 1. Activity of compounds 8a-c and 9a-c on MCF-7 cells, Leishmania amazonensis and Plasmodium falciparum (FcB1 strain)

\begin{tabular}{lccc}
\hline Comp. & \multicolumn{3}{c}{$\mathrm{IC}_{50}\left(\mu \mathrm{mol} \mathrm{L}^{-1} \pm \mathrm{SD}\right)$} \\
\hline $\mathbf{8 a}$ & MCF-7 & Leishmania & Plasmodium \\
$\mathbf{8 b}$ & $29.3 \pm 3.3$ & $9.60 \pm 0.18$ & $>10^{\mathrm{a}}$ \\
$\mathbf{8 c}$ & $5.3 \pm 0.7$ & $1.67 \pm 0.19$ & $0.88 \pm 0.09$ \\
9a & $7.8 \pm 0.6$ & $1.96 \pm 0.23$ & $2.50 \pm 0.11$ \\
9b & $19.3 \pm 7.1$ & $32.94 \pm 0.35$ & $0.28 \pm 0.13$ \\
9c & $12.5 \pm 3.8$ & $11.75 \pm 0.25$ & $0.03 \pm 0.01$ \\
A & $8.5 \pm 4.9$ & $6.80 \pm 0.14$ & $0.04 \pm 0.02$ \\
B & $\mathrm{ND}$ & $\mathrm{ND}$ & $0.145 \pm 0.011$ \\
C & $>38.0$ & $\mathrm{ND}$ & $\mathrm{ND}$ \\
\hline
\end{tabular}

(A), Chloroquine; (B), $\alpha$-lapachone; (C) Amphotericin B;22 aHighest value.

used as standard toward plasmodium, MCF-7 cells and leishmania, respectively.

All the compounds showed low toxicity to fresh murine lymphocytes (Table 2). Compound $\mathbf{8 c}$ presented the best safety ratio for MCF-7 (Lymphocytes / MCF-7 = 10.6). Although compounds $\mathbf{8 b}$ and $8 \mathrm{c}$ displayed similar activities on Leishmania amazonensis, $\mathbf{8 c}$ presented a higher level of therapeutic safety (Lymphocyte/Leishmania amazonensis ratio $=42.3$ ). The new series 9 a-c was very selective against malarial parasites, with ratios ranging from 257 to 1,829 .

Table 2. Cytotoxic effect of compounds 8a-c and 9a-c on fresh murine lymphocytes and their safety ratio toward MCF-7 tumor cells, Leishmania and Plasmodium as shown in Table1

\begin{tabular}{ccccc}
\hline & $\left.\begin{array}{c}\mathrm{IC}_{50} \\
(\mu \mathrm{mol} \mathrm{L}\end{array} \pm \mathrm{SD}\right)$ & \multicolumn{3}{c}{ Safety ratio } \\
\cline { 3 - 5 } Comp. & Lymph. & $\begin{array}{c}\text { Lymph / } \\
\text { MCF-7 }\end{array}$ & $\begin{array}{c}\text { Lymph / } \\
\text { Leish. }\end{array}$ & $\begin{array}{c}\text { Lymph / } \\
\text { Plasm }\end{array}$ \\
\hline $\mathbf{8 a}$ & $53.1 \pm 1.9$ & 1.8 & 5.5 & $<5.3$ \\
$\mathbf{8 b}$ & $33.0 \pm 1.8$ & 6.2 & 19.7 & 37.3 \\
$\mathbf{8 c}$ & $83.1 \pm 2.3$ & 10.6 & 42.3 & 33.2 \\
$\mathbf{9 a}$ & $72.3 \pm 2.2$ & 3.7 & $<3.6$ & 257.1 \\
$\mathbf{9 b}$ & $32.5 \pm 1.9$ & 2.6 & 2.7 & 969.6 \\
$\mathbf{9 c}$ & $75.1 \pm 2.1$ & 3.8 & 11.0 & $1,829.2$ \\
\hline
\end{tabular}

\section{Conclusion}

New bioactive pterocarpanquinones were prepared through a new oxa-Heck reaction between chromenequinone $\mathbf{1 0}$ and ortho-mercury benzyl alcohols 12a-c. Based on in vitro assays it was possible to discover active compounds with selective antitumoral, antileishmanial and antimalarial activities. The safety ratio for MCF-7 cells was lower than 
observed for both parasites. This is not surprising, since lymphocytes are genetically more similar to mammalian carcinoma cells than to protozoan parasites.

Work is now in progress to identify the biological targets of these compounds and to prepare new derivatives for SAR (structure activity relationship) studies through palladium catalyzed oxa-Heck reaction. In particular, the development of new compounds with antimalarial properties sharing the new molecular architecture represented by series 9 compounds is a very promising possibility. Conversely, compounds of series $\mathbf{8}$ show a higher potential for the development of antileishmanial and antitumoral drugs.

\section{Experimental}

\section{Chemistry}

Melting points were determined with a Thomas-Hoover apparatus and are uncorrected. Column chromatography was performed on silica gel 230-400 mesh (Aldrich). ${ }^{1} \mathrm{H}$ NMR spectrum was recorded on a Bruker Avance 400 (400.013 MHz) spectrometer at ambient temperature. All $J$ values are given in $\mathrm{Hz}$. Chemical shifts are expressed in parts per million downfield shift from tetramethylsilane as an internal standard, and reported as position $(\delta \mathrm{H})$ (relative integral, multiplicity $(\mathrm{s}=$ singlet, $\mathrm{d}=$ doublet, $\mathrm{dd}=$ double doublet, $\mathrm{dt}=$ double triplet, $\mathrm{m}=$ multiplet), coupling constant $(J \mathrm{~Hz})$ and assignment. ${ }^{13} \mathrm{C}$ NMR spectrum was recorded on a Bruker Avance 400 (100.003 MHz) spectrometer at ambient temperature with complete proton decoupling. Data are expressed in parts per million downfield shift from tetramethylsilane as an internal standard and reported as position $(\delta \mathrm{C})$.

General procedure for the oxa-Heck or oxy-arylation reaction to naphthoquinone $(\mathbf{9 d})$, as an example

To a mixture of $\mathrm{PdCl}_{2}(28.31 \mathrm{mg}, 0.16 \mathrm{mmol})$ and $\mathrm{LiCl}$ $(13.6 \mathrm{mg}, 0.32 \mathrm{mmol})$ in dry acetone $(5 \mathrm{~mL})$ was added chromene 10 (34 mg, $0.16 \mathrm{mmol})$ in dry acetone $(10 \mathrm{~mL})$. This mixture was stirred for $15 \mathrm{~min}$ at $0{ }^{\circ} \mathrm{C}$ and then 2-chloromercurio-4-benzyloxy-5-methoxy-benzylalcohol 12b $(79 \mathrm{mg}, 0.16 \mathrm{mmol})$ in dry acetone $(10 \mathrm{~mL})$ was added. The suspension thus obtained was stirred for $12 \mathrm{~h}$ at $25{ }^{\circ} \mathrm{C}$. After this time, brine $(30 \mathrm{~mL})$ was added and the reaction mixture was extracted with ethyl acetate $(100 \mathrm{~mL})$. The organic layer was dried $\left(\mathrm{Na}_{2} \mathrm{SO}_{4}\right)$, evaporated and the resulting oil was purified by column chromatography, furnishing compound $9 \mathrm{~d}$ as a yellow solid (36 $\mathrm{mg}, 50 \%$ ), $\mathrm{mp} 205^{\circ} \mathrm{C} .{ }^{1} \mathrm{H} \mathrm{NMR}\left(\mathrm{CDCl}_{3}\right) \delta 2.84(\mathrm{dt}, J 12.18,3.66 \mathrm{~Hz}$, $1 \mathrm{H}), 3.88(\mathrm{~s}, 3 \mathrm{H}), 4.16(\mathrm{dd}, J 12.40,11.00 \mathrm{~Hz}, 1 \mathrm{H})$,
4.36 (ddd, $J$ 12.70, 4.65, $1.72 \mathrm{~Hz}, 1 \mathrm{H}), 4.78$ (d, $J 14.92$ $\mathrm{Hz}, 1 \mathrm{H}$ ), 4.88 (dd, J 2.93, $1.74 \mathrm{~Hz}, 1 \mathrm{H}), 5.00$ (d, $J 14.74$ $\mathrm{Hz}, 1 \mathrm{H}), 5.16$ (s, 2H), 6.60 (s, 1H), $6.66(\mathrm{~s}, 1 \mathrm{H}), 7.38$ $(\mathrm{m}, 5 \mathrm{H}), 7.74(\mathrm{~m}, 2 \mathrm{H}), 8.14(\mathrm{~m}, 2 \mathrm{H}) ;{ }^{13} \mathrm{C} \mathrm{NMR}\left(\mathrm{CDCl}_{3}\right)$ $\delta 34.01(\mathrm{CH}), 55.87\left(\mathrm{CH}_{3}\right), 63.28(\mathrm{CH}), 67.63\left(\mathrm{CH}_{2}\right), 68.06$ $\left(\mathrm{CH}_{2}\right), 71.20\left(\mathrm{CH}_{2}\right), 107.69(\mathrm{CH}), 114.83(\mathrm{CH}), 118.85$ (C), $121.39(\mathrm{C}), 126.29(\mathrm{CH}), 127.16(\mathrm{CH}), 127.83(\mathrm{CH})$, $127.97(\mathrm{C}), 128.44(\mathrm{CH}), 130.65(\mathrm{C}), 131.94(\mathrm{C}), 133.09$ $(\mathrm{CH}), 134.36(\mathrm{CH}), 136.63(\mathrm{C}), 146.90(\mathrm{C}), 149.39(\mathrm{C})$, 156.25 (C), 179.77 (C), 182.87 (C).

Naphthoquinone (9a). After column chromatography this compound was obtained as a brown solid in $30 \%$ yield, mp $215{ }^{\circ} \mathrm{C} .{ }^{1} \mathrm{H}$ NMR $\left(\mathrm{CDCl}_{3}\right) \delta 2.90(\mathrm{dt}, J 12.45$, $3.66 \mathrm{~Hz}, 1 \mathrm{H}), 4.24(\mathrm{dd}, J 12.46,10.99 \mathrm{~Hz}, 1 \mathrm{H}), 4.52$ (ddd, $J$ 12.82, 4.76, $1.83 \mathrm{~Hz}, 1 \mathrm{H}), 4.78(\mathrm{~d}, J 14.65 \mathrm{~Hz}$, 1H), $4.90(\mathrm{dd}, J 2.93,1.83 \mathrm{~Hz}, 1 \mathrm{H}), 4.80(\mathrm{~d}, J 14.65 \mathrm{~Hz}$, $1 \mathrm{H}), 5.96(\mathrm{~d}, J 2.57 \mathrm{~Hz}, 1 \mathrm{H}), 5.98(\mathrm{~d}, J 2.19 \mathrm{~Hz}, 1 \mathrm{H})$, $6.57(\mathrm{~s}, 1 \mathrm{H}), 6.70(\mathrm{~s}, 1 \mathrm{H}), 7.78(\mathrm{~m}, 2 \mathrm{H}), 8.19(\mathrm{~m}, 2 \mathrm{H}) ;{ }^{13} \mathrm{C}$ NMR $\left(\mathrm{CDCl}_{3}\right) \delta 34.74(\mathrm{CH}), 63.26(\mathrm{CH}), 67.99\left(\mathrm{CH}_{2}\right)$, $68.19\left(\mathrm{CH}_{2}\right), 101.04\left(\mathrm{CH}_{2}\right), 104.67(\mathrm{CH}), 108.67(\mathrm{CH})$, $118.81(\mathrm{C}), 122.67(\mathrm{C}), 126.39(\mathrm{CH}), 128.55(\mathrm{C}), 130.71$ (C), $131.99(\mathrm{C}), 133.19(\mathrm{CH}), 134.45(\mathrm{CH}), 146.62(\mathrm{C})$, 147.23 (C), 156.30 (C), 179.82 (C), 182.95 (C). IR (KBr) $v_{\text {max }} / \mathrm{cm}^{-1}: 2896$ (aromatic H), $1684(\mathrm{C}=\mathrm{O}), 1649(\mathrm{C}=\mathrm{O})$. High resolution mass spectrometry $(\mathrm{M}+\mathrm{H})$ : calculated 363.0869, founded 363.1006.

Naphthoquinone (9e). After column chromatography this compound was obtained as a orange solid in $20 \%$ yield, $\mathrm{mp} 230{ }^{\circ} \mathrm{C} .{ }^{1} \mathrm{H} \mathrm{NMR}\left(\mathrm{CDCl}_{3}\right) \delta 2.87(\mathrm{~m}, 1 \mathrm{H}), 3.92(\mathrm{~s}, 3 \mathrm{H})$, 4.28 (dd, $J 12.45,10.99 \mathrm{~Hz}, 1 \mathrm{H}), 4.55$ (ddd, $J$ 10.99, 4.39, $1.83 \mathrm{~Hz}, 1 \mathrm{H}), 4.74(\mathrm{~d}, J 15.01 \mathrm{~Hz}, 1 \mathrm{H}), 4.92(\mathrm{dd}, J$ 2.93, $1.83 \mathrm{~Hz}, 1 \mathrm{H}), 4.98(\mathrm{~d}, J 15.02 \mathrm{~Hz}, 1 \mathrm{H}), 5.14(\mathrm{~s}, 2 \mathrm{H}), 6.60$ (s, 1H), $6.72(\mathrm{~s}, 1 \mathrm{H}), 7.40(\mathrm{~m}, 5 \mathrm{H}), 7.74(\mathrm{~m}, 2 \mathrm{H}), 8.16(\mathrm{~m}$, $2 \mathrm{H}) ;{ }^{13} \mathrm{C} \mathrm{NMR}\left(\mathrm{CDCl}_{3}\right) \delta 34.25(\mathrm{CH}), 56.08\left(\mathrm{CH}_{3}\right), 63.21$ $(\mathrm{CH}), 67.53\left(\mathrm{CH}_{2}\right), 68.12\left(\mathrm{CH}_{2}\right), 70.80\left(\mathrm{CH}_{2}\right), 109.64(\mathrm{CH})$, $112.06(\mathrm{CH}), 118.84(\mathrm{C}), 122.08(\mathrm{C}), 126.28(\mathrm{CH}), 127.08$ $(\mathrm{CH}), 127.22(\mathrm{C}), 127.79(\mathrm{CH}), 128.41(\mathrm{CH}), 130.62(\mathrm{C})$, $131.90(\mathrm{C}), 133.10(\mathrm{CH}), 134.36(\mathrm{CH}), 136.49(\mathrm{C}), 147.77$ (C), 148.59 (C), 156.25 (C), 179.76 (C), 182.89 (C).

General procedure for hydrogenolysis to naphthoquinone (9c), as an example

Naphthoquinone $(9 c)$. $(76 \mathrm{mg}, 0.17 \mathrm{mmol}$ ) in acetone was allowed to react with hydrogen ( $3 \mathrm{~atm})$ in the presence of Pd/C (10\%). After $3 \mathrm{~h}$ the catalyst was filtered and the product purified by flash chromatography using hexane:ethyl acetate (6:4) as eluant to give $9 \mathbf{c}(62 \mathrm{mg})$ in quantitative yield, $\mathrm{mp} 150{ }^{\circ} \mathrm{C} .{ }^{1} \mathrm{H}$ NMR (acetone-D) $\delta 2.96$ (dt, $J 12.09,8.60,3.48 \mathrm{~Hz}, 1 \mathrm{H}), 3.88$ (s, 3H), 4.08 (dd, $J$ $12.46,10.63 \mathrm{~Hz}, 1 \mathrm{H}), 4.60(\mathrm{ddd}, J 8.06,4.48,1.74 \mathrm{~Hz}, 1 \mathrm{H})$, 
$4.74(\mathrm{~d}, J 13.92 \mathrm{~Hz}, 1 \mathrm{H}), 4.8(\mathrm{~m}, 2 \mathrm{H}), 6.60(\mathrm{~s}, 1 \mathrm{H}), 7.00(\mathrm{~s}$, $1 \mathrm{H}), 7.84(\mathrm{~m}, 2 \mathrm{H}), 8.06(\mathrm{~m}, 2 \mathrm{H}) ;{ }^{13} \mathrm{C}$ NMR (acetone-D) $\delta$ $34.96(\mathrm{CH}), 56.30\left(\mathrm{CH}_{3}\right), 64.49(\mathrm{CH}), 68.17\left(\mathrm{CH}_{2}\right), 68.72$ $\left(\mathrm{CH}_{2}\right), 111.67(\mathrm{CH}), 113.10(\mathrm{CH}), 118.53(\mathrm{C}), 120.00$ $(\mathrm{CH}), 122.11(\mathrm{CH}), 126.67(\mathrm{CH}), 126.73(\mathrm{CH}), 128.86$ (C), $131.97(\mathrm{C}), 132.99(\mathrm{C}), 134.10(\mathrm{CH}), 135.20(\mathrm{CH})$, 146.94 (C), 147.50 (C), 157.12 (C), 180.17 (C), 183.19 (C). IR (KBr) $v_{\text {max }} / \mathrm{cm}^{-1}: 3414(\mathrm{OH}), 2927$ (aromatic H), $1681(\mathrm{C}=\mathrm{O}), 1620(\mathrm{C}=\mathrm{O})$.

Naphthoquinone $(\mathbf{9 b})$. This compound was obtained after column chromatography (hexane:ethyl acetate (6:4)) as a orange solid in quantitative yield $(62 \mathrm{mg}), \mathrm{mp} 145^{\circ} \mathrm{C}$. ${ }^{1} \mathrm{H}$ NMR (acetone-D) $\delta 2.96(\mathrm{~m} \mathrm{1H}), 3.84(\mathrm{~s}, 3 \mathrm{H}), 4.08$ (dd, $J 12.46,10.72 \mathrm{~Hz}, 1 \mathrm{H}), 4.54$ (ddd, $J 12.39,4.51,1.66$ $\mathrm{Hz}, 1 \mathrm{H}), 4.72$ (d, J $14.65 \mathrm{~Hz}, 1 \mathrm{H}), 4.8$ (m, 2H), 6.74 (s, 1H), $6.86(\mathrm{~s}, 1 \mathrm{H}), 7.86(\mathrm{~m}, 2 \mathrm{H}), 8.08(\mathrm{~m}, 2 \mathrm{H})$. IR (KBr) $v_{\max } / \mathrm{cm}^{-1}: 3414(\mathrm{OH}), 2928$ (aromatic H), $1679(\mathrm{C}=\mathrm{O})$, $1650(\mathrm{C}=\mathrm{O})$.

\section{Biological assays}

Antimalarial activity. Plasmodium falciparum (FcB1-Columbia), a chloroquine-resistant strain (chloroquine $\mathrm{IC}_{50}: 145 \pm 11.2 \mathrm{nmol} \mathrm{L} \mathrm{L}^{-1}$ ), was cultured according to the method described by Trager and Jensen, ${ }^{23}$ with modifications. ${ }^{24}$ Cultures were synchronized by $5 \%$ D-sorbitol lysis (Merck, Darmstadt, Germany). ${ }^{25}$ In vitro antimalarial activity testing was evaluated by $\left[{ }^{3} \mathrm{H}\right]$-hypoxanthine (ICN, France) incorporation as described by Desjardins et al. ${ }^{26}$ with modifications. ${ }^{25}$ Incubation time between parasite culture and the drugs was $48 \mathrm{~h}$.

Antitumoral activity. The antitumoral activity was estimated on human breast cancer cells (MCF-7). This cell line was cultured in the same conditions as P. falciparum, except for the 5\% human serum in MCF-7 instead of 5\% fetal calf serum (Boehringer) in Plasmodium. After addition of drugs in varying concentrations, cell growth inhibition was determined by $\left[{ }^{3} \mathrm{H}\right]$-hypoxanthine incorporation after a $48 \mathrm{~h}$ incubation. ${ }^{27}$

Antileishmanial activity. The antileishmanial activity was fluorimetrically determined against promastigote forms of L. amazonensis (Josefa strain) parasites transfected with the green fluorescence protein (GFP) ${ }^{28,29}$ Fluorescent promastigotes were plated in triplicate at $10^{5}$ parasites/ well with varying concentrations of test compounds in a final volume of $200 \mu \mathrm{L}$ of medium containing 5\% fetal calf serum and $1 \%$ hybri-max dimethyl sulfoxide (DMSO, Sigma). After $72 \mathrm{~h}$ at $26{ }^{\circ} \mathrm{C}$, the fluorescence intensity of the cultures was measured using a plate-reader fluorometer (Bio-Tek) set at $435 \mathrm{~nm}$ excitation $/ 538 \mathrm{~nm}$ emission. The $\mathrm{IC}_{50}$ values were calculated by linear regression analysis.
Cytotoxicity against lymphocytes. For cytotoxicity against mammalian cells, total murine lymph node cells (mostly lymphocytes) were cultured for $48 \mathrm{~h}$ at $37^{\circ} \mathrm{C}$ with varying concentrations of the test compounds. The release of the cytoplasmic enzyme lactate dehydrogenase (LDH) into the culture medium was measured using an assay kit (Doles Reagentes, Brazil). Maximum and minimum release values were obtained using cells cultured with $2 \%$ Triton $\mathrm{X}-100$ or with no drugs, respectively. The $\mathrm{IC}_{50}$ values were calculated by linear regression analysis.

\section{Acknowledgments}

LQB, NPPN-UFRJ (Brazil) was supported by grants from PRONEX/FAPERJ, FAPERJ, CAPES, FINEP and CNPq. C.D.N., B.R.B and P.R.R.C are CNPq fellows. W.P.L. is CAPES fellows. We are grateful to Prof. Marcus Eberlin (IQ-UNICAMP) for high resolution mass spectrometry and Central Analítica NPPN-UFRJ for the analytical data.

\section{References}

1. Kamat, V. S.; Chuo, F. Y.; Kubo, I.; Nakanishi, K.; Heterocycles 1981, 15, 1163; Mitscher, L. A.; Drake, S.; J. Nat. Prod. 1987, 50,1025 .

2. Chilpa, R. R.; Estrada, M. J.; Interciencia 1995, 20, 257.

3. Boyd, M.; Mckee, T. C.; Bokesch, H. R.; McCormick, J. L.; Rashid, M. A.; Spielvogel, D.; Gustafson, K. R.; Alavanja, M. M.; Cardellina, J. H.; J. Nat. Prod. 1997, 60, 431.

4. Lin, M.; Tsao, L.; Huang, L.; Kuo, S.; Weng, J.; Ko, H.; Lin, C.; Lee, M.; Wang, J.; Toxicol. Appl. Pharm. 2006, 210, 108; Veitch, N. C.; Nat. Prod. Rep. 2007, 24, 417.

5. Chaudhuri, S. K.; Huang, L.; Fullas, F.; Brown, D. M; Wani, M. C.; Wall, M. E.; J. Nat. Prod. 1995, 58, 1966; Gottlieb, O. R.; Cook, J. T.; Ollis, W. D.; Sutherland, I. O.; Phytochemistry 1978, 17, 1419; Salem, M. M.; Werbovetz, Karl, A.; J. Nat. Prod. 2006, 69, 43.

6. Netto, C. D.; Santos, E. S. J.; Castro, C. P.; da Silva, A. J. M.; Rumjanek, V. M.; Costa, P. R. R.; European J. Med. Chem. DOI: 10.1016/j.ejmech.2008.01.027; da Silva, A. J. M.; Netto, C. D.; Costa, P. R. R.; J. Braz. Chem. Soc. 2004, 15, 979; Netto, C. D.; M. Sc. Dissertation, Universidade Federal do Rio de Janeiro, Brazil, 2003.

7. Park, H. J.; Ahn, K.J.; Ahn, S. D.; Choi, E.; Lee, S. W.; Williams, B.; Kim, E. J.; Griffin, R.; Bey, E. A.; Bornmann, W. G.; Gao J.; Park, H. J.; Boothman, D. A.; Song, C. W.; Int. J. Radiation Oncology Biol. Phys. 2005, 61, 212; Pink, J. J.; Planchon, S. M.; Tagliarino, C.; Varnes, M. E.; Siegel, D.; Boothman, D. A.; J. Biol. Chem. 2000, 275, 5416; Cavalieri, E. L.; Rogan, E. G.; Chakravarti, D. Cell. Mol. Life Sci. 2002, 59, 665; Cavalieri, E. 
L.; Li, K-M; Balu, N.; Saeed, M.; Davanesan, P.; Higginbotham, S.; Zhao, J.; Gross, M. L.; Rogan, E. G. Carcinogenesis 2002, 23, 1071 .

8. da Silva, A. J. M.; Buarque, C. D.; Brito, F. V.; Aurelian, L.; Macedo, L. F.; Malkas, L. H.; Hickey, R. J.; Lopes, D. V. S.; Nöel, F.; Murakami, Y. L. B.; Silva, N. M. V.; Melo, P. A.; Caruso, R. R. B.; Castro, N. G.; Costa, P. R. R. Bioorg. Med. Chem. 2002, 10, 2731.

9. de Moura, K. C. G.; Emery, F. S.; Neves-Pinto, C.; Pinto, M. C. F. R.; Dantas, A. P.; Salomão, K.; de Castro, S. L.; Pinto, A. V.; J. Braz. Chem. Soc. 2001, 12, 325; da Silva, M. N., Ferreira, V. F.; de Souza, M. C. B. V.; Quim. Nova 2003, 26, 407.

10. Spartan 02; Wavefunction Inc., Program for Molecular Modelling; Irvine, CA 2001

11. Chau Y.; Shiah, S.; Don M.; Kuo, M.; Free Radical Biol. Med. 1998, 24, 660 .

12. WHO Expert Comitee on Malaria: 20th report. (World Health Organization, Geneva, 2000)

13. Rath, S.; Trivelin, L. A.; Imbrunito, T. R.; Tomazela, D. M.; Jesús, M. N.; Marzal, P. C.; Quim. Nova 2003, 26, 550.

14. Skouta, R.; Li, C.; Tetrahedron Lett. 2007 48, 8343; Gopalsamy, A.; Balasubramanian, K. K.; J. Chem. Soc. Chem. Comm. 1988, 28; van Aardt, T. G.; Van Rensburg H.; Ferreira, D.; Tetrahedron 2001, 57, 7113; Engler, T. A.; Combrick, K. D.; Reddy, J. P.; J. Chem. Soc. Chem. Commun. 1989, 454; Whiting, D. A.; Mohamed, S. E. M.; Thomas, P.; J. Chem. Soc. Perkin Trans. I, 1987, 431; Fukui, K.; Nakayama, M.; Tetrahedron Lett. 1966, 7, 1805.

15. Horino, H.; Inoue, N.; J. Chem. Soc. Chem. Comm. 1976, 500; Pôças, E. S. C.; Lopes, D. V. S.; da Silva, A. J. M.; Pimenta, P. H. C.; Leitão, F. B.; Netto, C. D.; Buarque, C. D.; Brito, F. V.; Costa, P. R. R.; Noel, F. Bioorg. Med. Chem. 2006, 14, 7962 and cited references; Breytenbach, J. C.; Rall, G. J. H.; J. Chem. Soc., Perkin Trans. 1 1980, 1804; Ishiguro, M.; Tatsuoka, T.; Nakatsuka, N.; Tetrahedron Lett. 1982, 23, 3859; Breytenbach; J. C.; Rall, G. J. H.; Roux; D. G.; J. Chem. Soc., Perkin Trans. 1 1981, 2604; Narkhede, D. D.; Iyer, P. R.; Iyer, C. S. R.; J. Nat. Prod. 1989, 502; Simas, A. B. C.; da Silva, A. J. M.; Coelho, A. L.; Costa, P. R. R.; Tetrahedron Lett. 2001, 42, 4111; da Silva, A. J. M.; Coelho, A. L.; Simas, A. B. C.; Moraes, R. A. M.; Pinheiro, D. A.; Fernandes, F. F. A.; Arruda, E. Z.; Costa,
P. R. R.; Melo, P. A.; Bioorg. Med. Chem.Lett. 2004, 14, 431; Sant'Anna, S. S.; Evangelista, E. A.; Alves, R. B.; Raslan, D. S.; Chem. Nat. Compounds 2005, 41, 385; Lichetenfels, R. A.; Coelho, A. L.; Costa, P. R. R.; J. Chem. Soc. Perkin Trans. 1 $1995,949$.

16. Larock, R. C.; U. S. Patent. 5,721,371 1998.

17. Kiss, L.; Kurtán, T.; Antus,S.; Brunner, H. Arkivoc 2003, 69.

18. Li, C. C.; Xie, Z. X.; Zhang, Y. D.; Chen, J. H.; Yang, Z.; J. Org. Chem. 2003, 68, 8500; Das, B.; Krishnaiah, M.; Venkateswarlu, K.; Reddy, V. S.; Tetrahedron Lett. 2007, 48, 81; Yadav, J. S.; Reddy, B. V. S.; Reddy, P. S. R.; Basak, A. K.; Narsaiah, A. V.; Adv. Synth. Catal. 2004, 346, 77.

19. Pinho, V. D.; MSc Dissertation, Universidade Federal do Rio de Janeiro, Brazil, 2008.

20. Günther, H.; NMR-Spektroskopie, 3 auflage, George Thieme: Stuttgart, 1992, ch. 4.

21. Majumdar, K. C.; Biswas, A.; Mukhopadhyay, P. P.; Synthesis 2003, 15, 2385.

22. Mi, Q.; Lantvit, D.; Reyes-Lim, E.; Chai, H.; Zhao, W.; Lee, I.; Peraza-Sánchez, S.; Ngassapa, O.; Kardono, L. B. S.; Riswan, S.; Hollingshead, M. G.; Mayo, J. G.; Farnsworth, N. R.; Cordell, G. A.; Kinghorn, A. D.; Pezzuto J. M.; J. Nat. Prod. 2002, 65, 842 .

23. Trager W.; Jensen J. B.; Science 1976, 193, 673.

24. Benoit, F.; Valentin, A.; Pélissier, Y.; Marion, C.; Dakuyo, Z.; Mallié, M.; Bastide, J.-M.; Trans. Roy. Soc. Trop. Med. Hyg. 1995, 89, 217.

25. Lambros, C.; Vanderberg, J. P.; J. Parasitol., 1979, 65, 418.

26. Desjardins, R. E.; Canfield, C. J.; Haynes, J. D.; Chulay, J. D.; Antimicrob. Agents Chemother. 1979, 16, 710.

27. Valentin, A.; Benoit-Vical, F.; Moulis, C.; Stanislas, E.; Mallié, M.; Fourasté, I.; Bastide, J.-M.; Antimicrob. Agents Chemother. 1997, 41, 2305.

28. Rossi-Bergmann, B. A.; Lenglet, C. R.; Bezerra-Santos, D.; Costa-Pinto, Y. M.; Traub-Czeko, A.; Mem. I. Oswaldo Cruz 1999, 94, SII74.

29. Boeck, P.; Falcão, C. A. B.; Leal, C. P; Yunes, R. A.; Filho, V. C.; Torres-Santos, E. C.; Rossi-Bergmann, B. A.; Bioorg. Med. Chem. 2006, 14, 1538.

Received: June 5, 2008 Web Release Date: November 28, 2008 


\section{Antitumoral, Antileishmanial and Antimalarial Activity of Pentacyclic 1,4-Naphthoquinone Derivatives}

\section{Alcides J.M. da Silva, ${ }^{*, a}$ Chaquip D. Netto, ${ }^{a}$ Wallace Pacienza-Lima, ${ }^{b}$ Eduardo Caio Torres-Santos, ${ }^{b, c}$ Bartira Rossi-Bergmann, ${ }^{b}$ Severine Maurel, ${ }^{d}$ Alexis Valentin ${ }^{d}$ and Paulo R.R. Costa ${ }^{*, a}$}

${ }^{a}$ Laboratório de Química Bioorgânica, Núcleo de Pesquisas de Produtos Naturais; Centro de Ciências da Saúde, Bloco H, Universidade Federal do Rio de Janeiro-RJ 21941-590, Brazil

${ }^{b}$ Instituto de Biofísica Carlos Chagas Filho; Centro de Ciências da Saúde, Bloco G, Universidade Federal do Rio de Janeiro, Rio de Janeiro-RJ 21941-590, Brazil

'Laboratório de Bioquímica de Tripanosomatídeos, Instituto Oswaldo Cruz, Rio de Janeiro-RJ 21045-900, Brazil

${ }^{d}$ UMR 152, IRD Université Paul Sabatier, Pharmacochimie des Substances Naturelles et Pharmacophores Redox. Faculté de Pharmacie, 118 route de Narbonne, F-31062 Toulouse Cedex 4, France

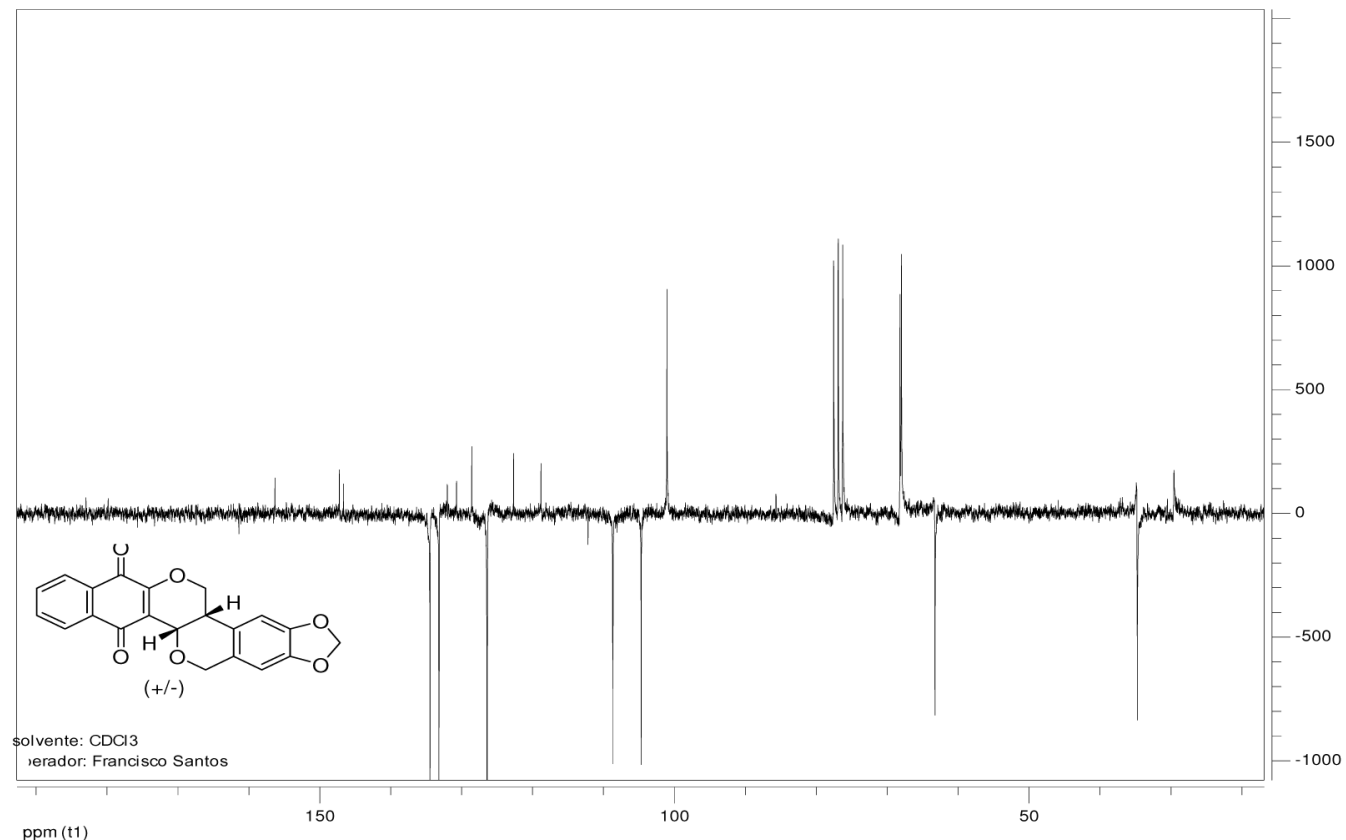

Figure S1. ${ }^{13} \mathrm{C}$ NMR (APT) spectrum for compound 9a. 


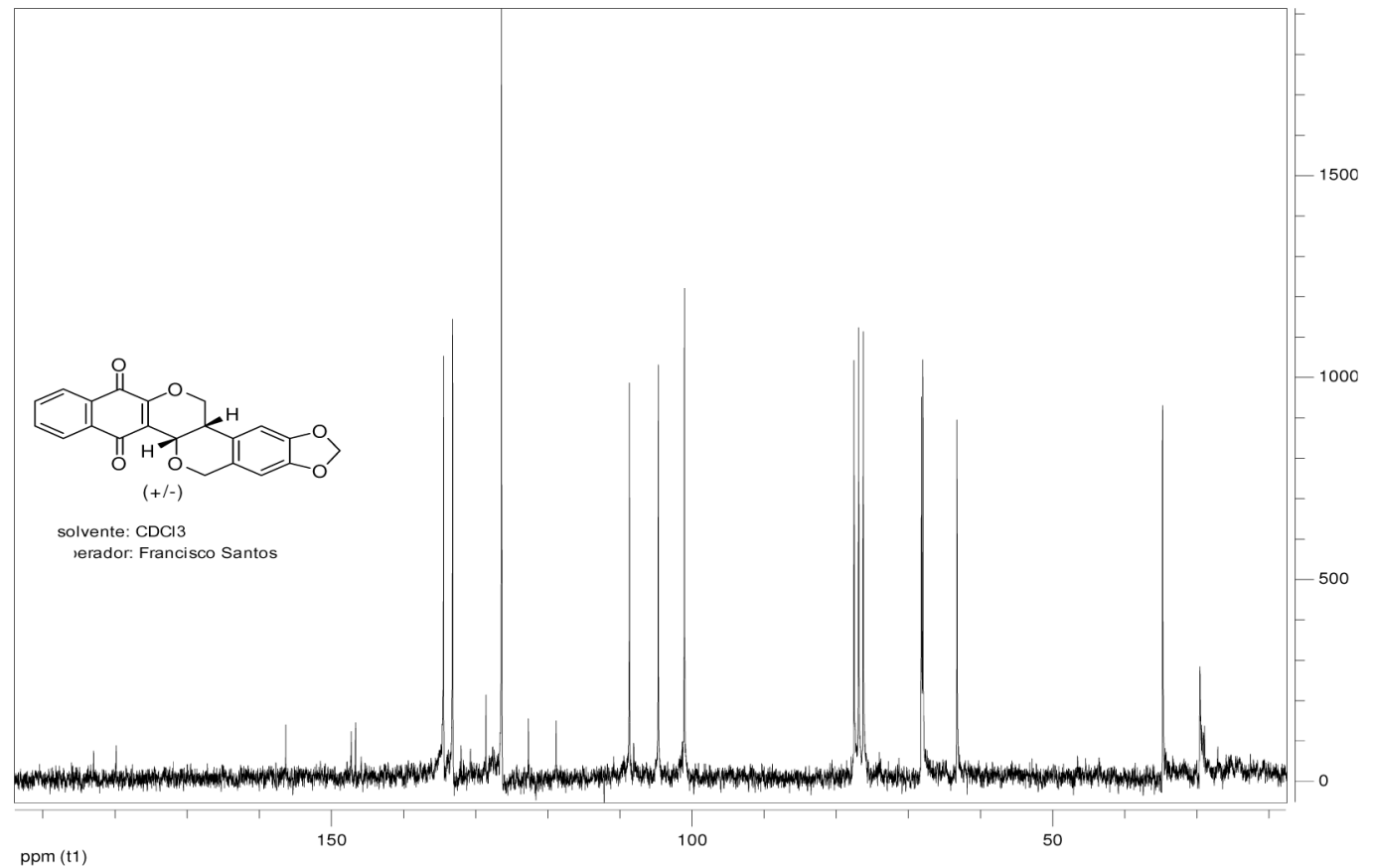

Figure S2. ${ }^{13} \mathrm{C}$ NMR spectrum for compound 9a.

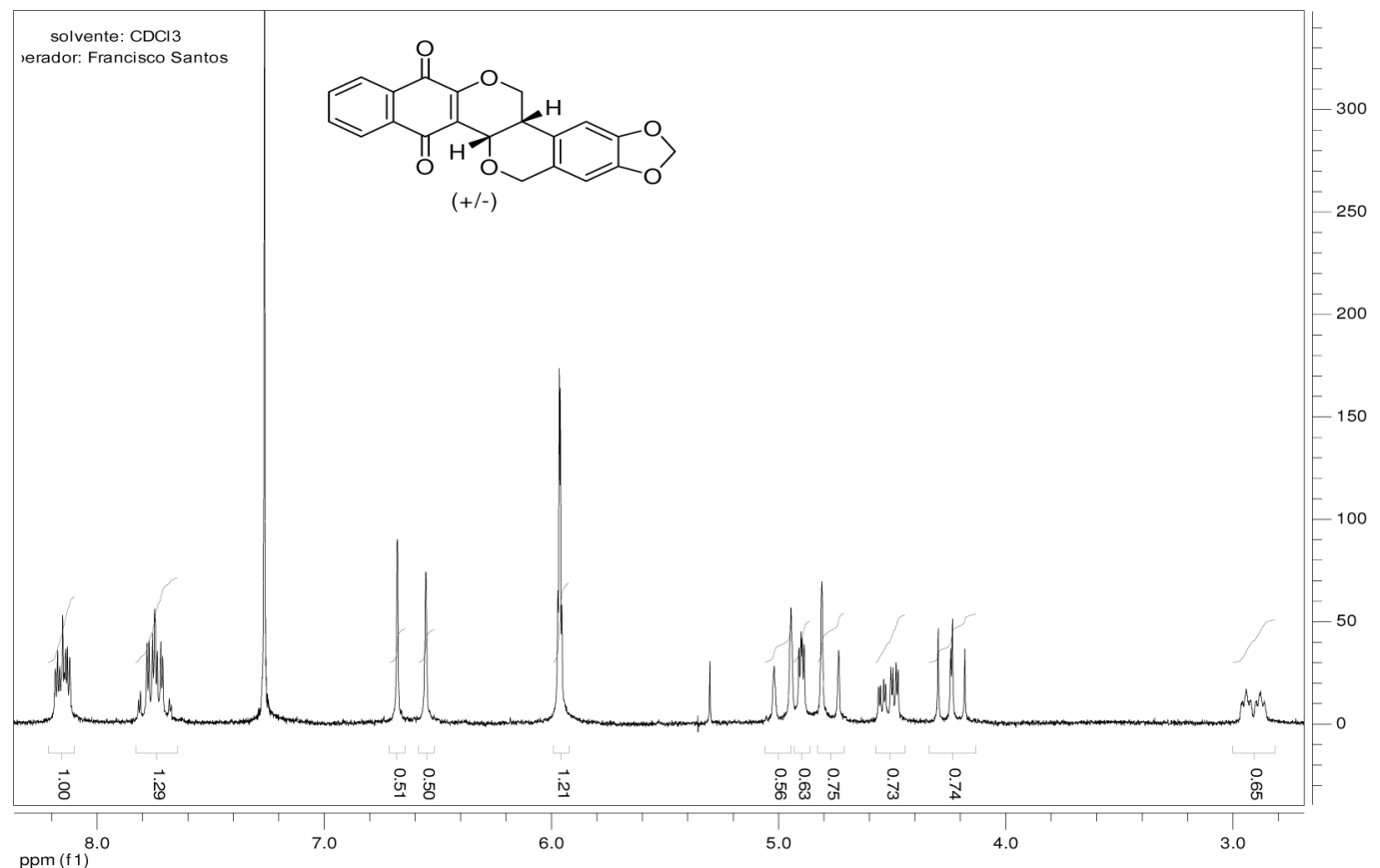

Figure S3. ${ }^{1} \mathrm{H}$ NMR spectrum for compound 9a 
UNIVERSIDADE DO ESTADO DO RIO DE JANEIRO

Instituto de Química - Departamento de Química Orgânica

Grupo de Polímeros - GPol

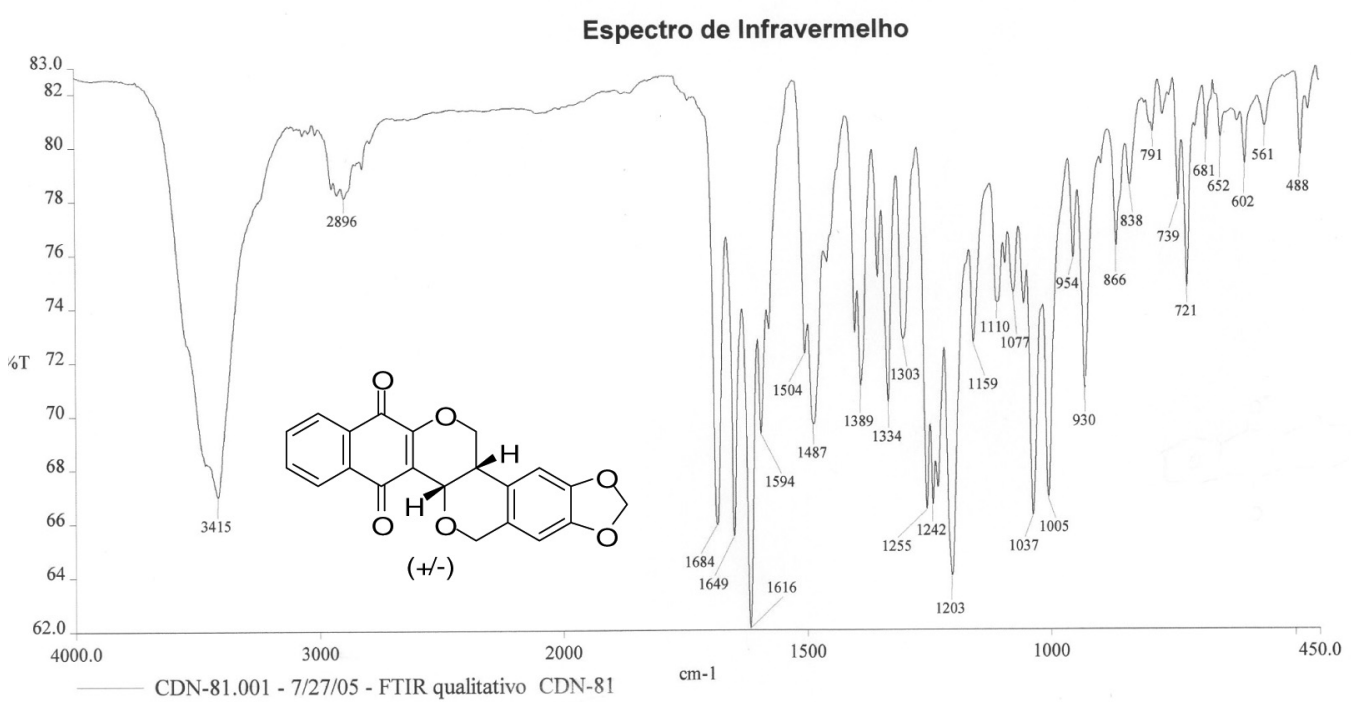

Figure S4. Infra Red spectrum for compound 9a.

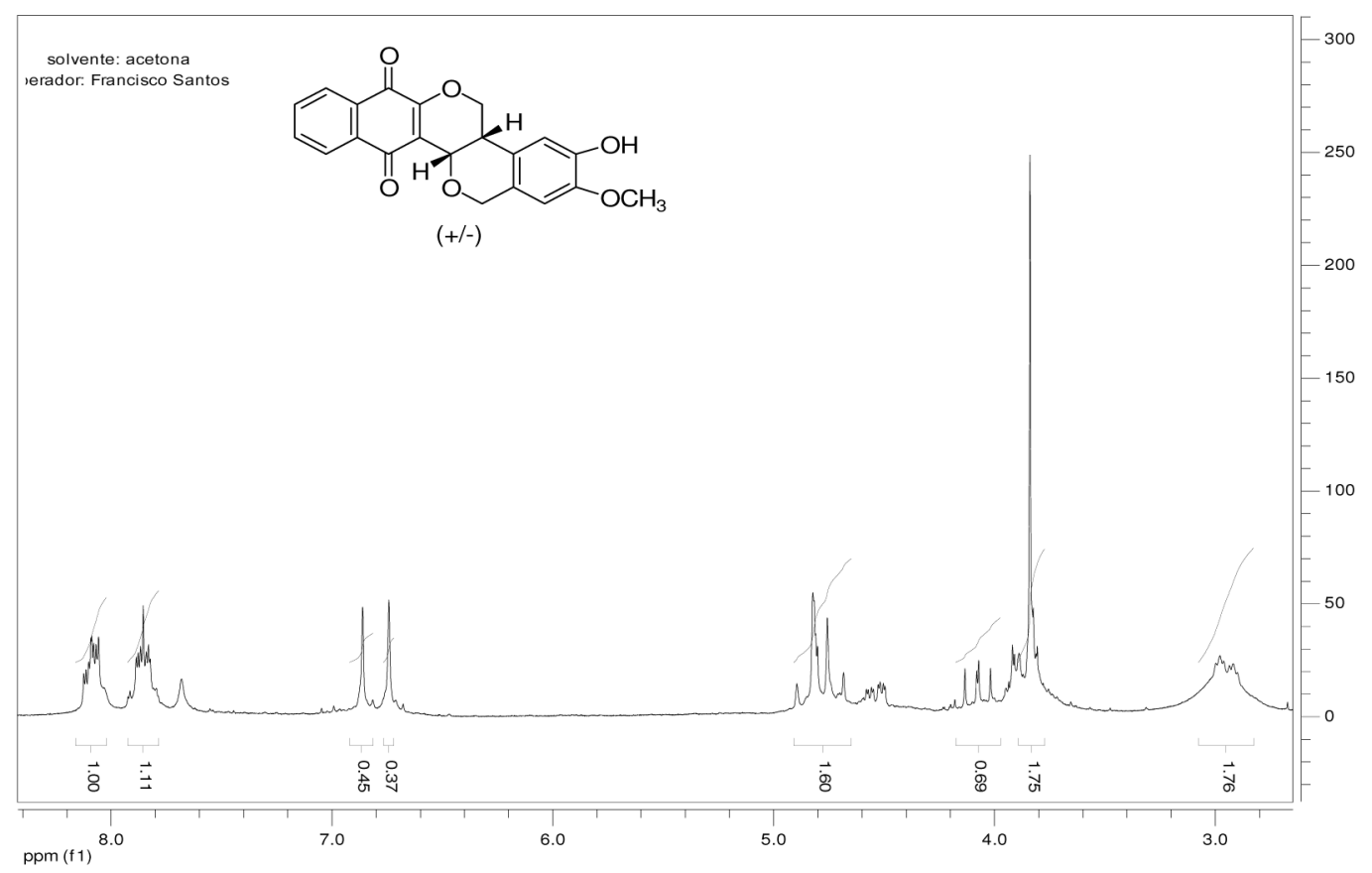

Figure S5. ${ }^{1} \mathrm{H}$ NMR spectrum for compound $\mathbf{9 b}$. 
UNIVERSIDADE DO ESTADO DO RIO DE JANEIRO

Instituto de Química - Departamento de Química Orgânica

Grupo de Polímeros - GPol

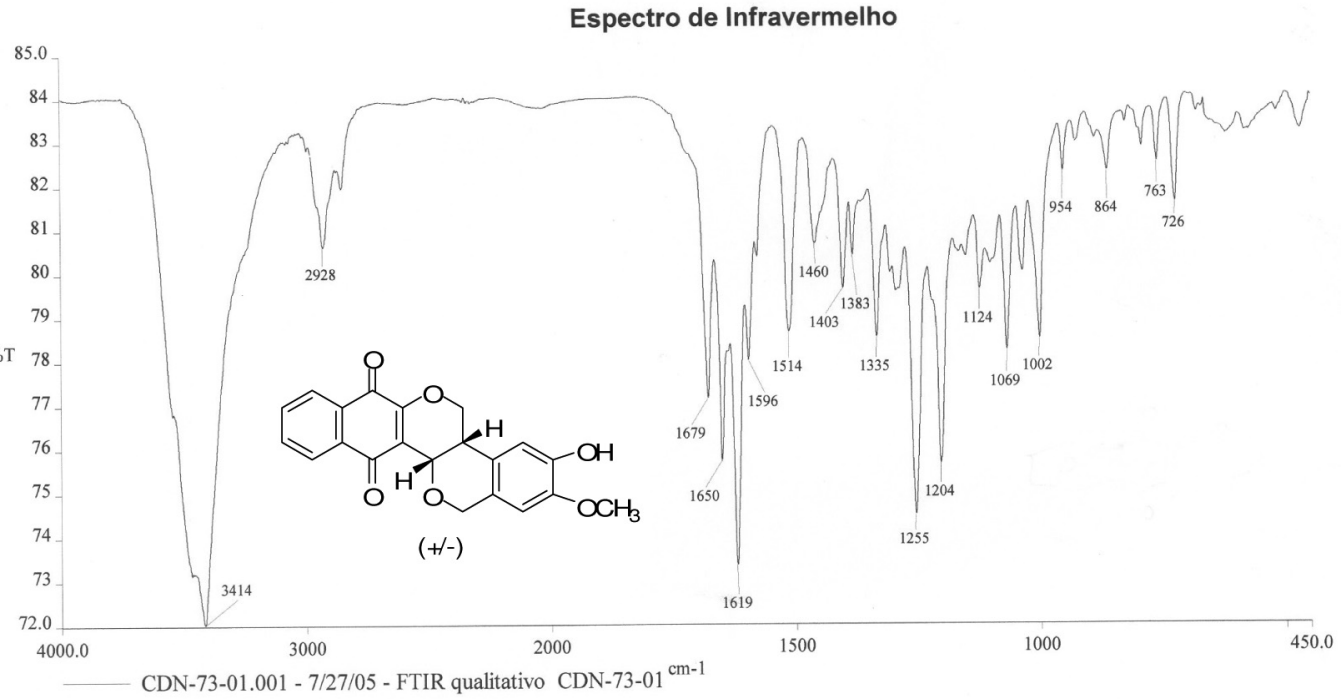

Figure S6. IR mass spectrum for compound $9 \mathrm{~b}$.

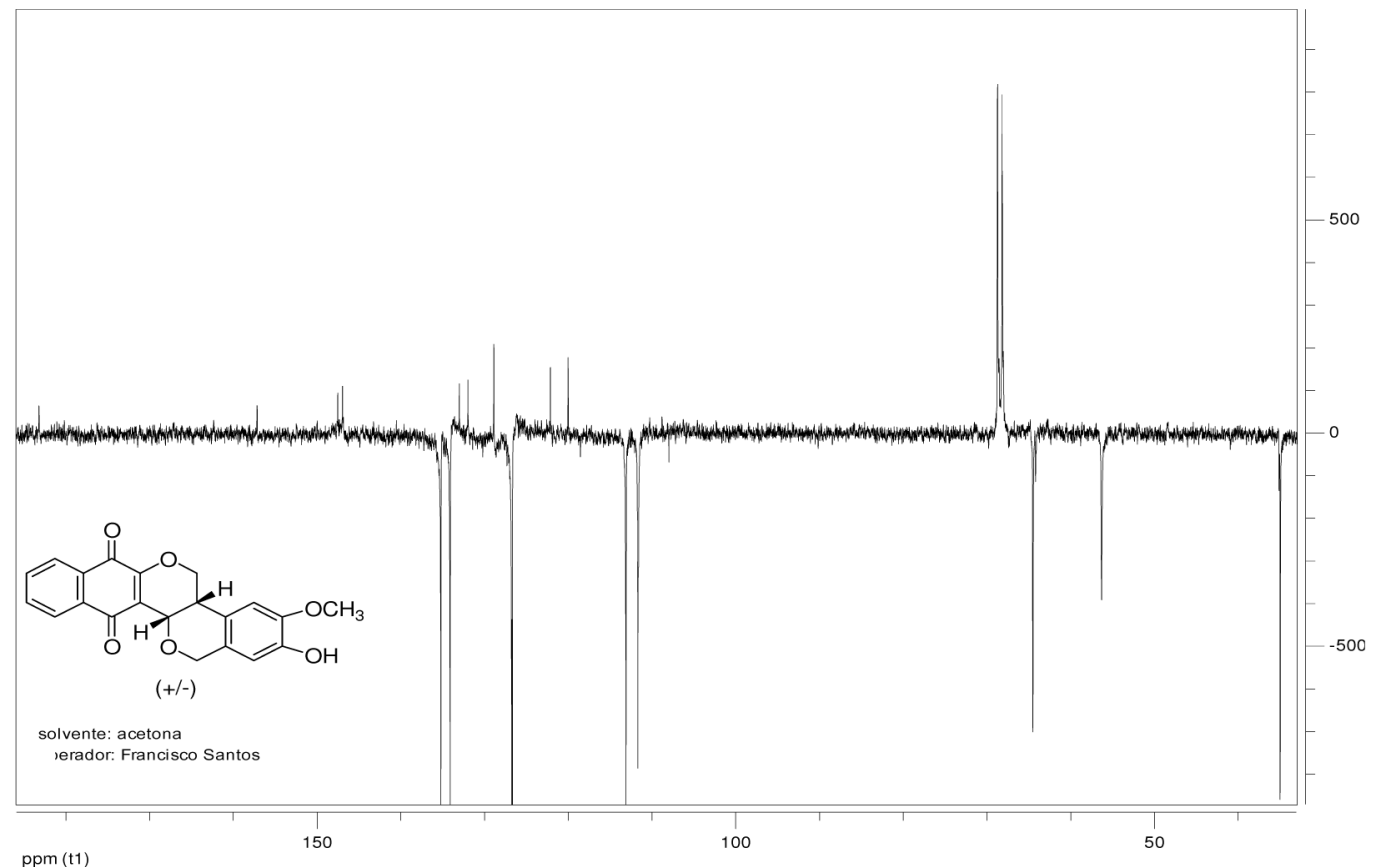

Figure S7. ${ }^{13} \mathrm{C}(\mathrm{APT}) \mathrm{NMR}$ spectrum for compound 9c. 
Vol. 20, No. 1, 2009

da Silva et al.

5

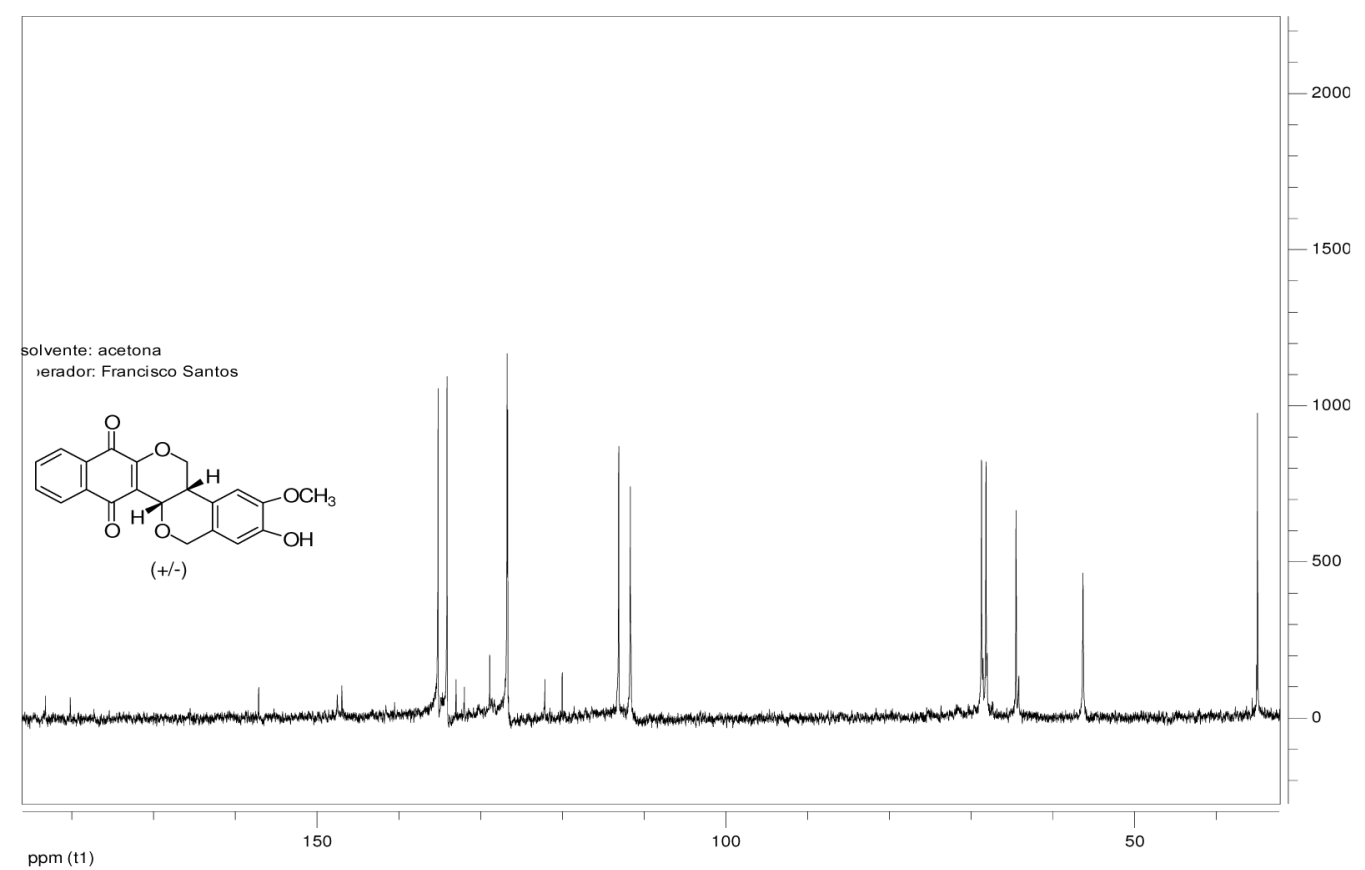

Figure S8. ${ }^{13} \mathrm{C}$ NMR spectrum for compound $\mathbf{9 c}$.

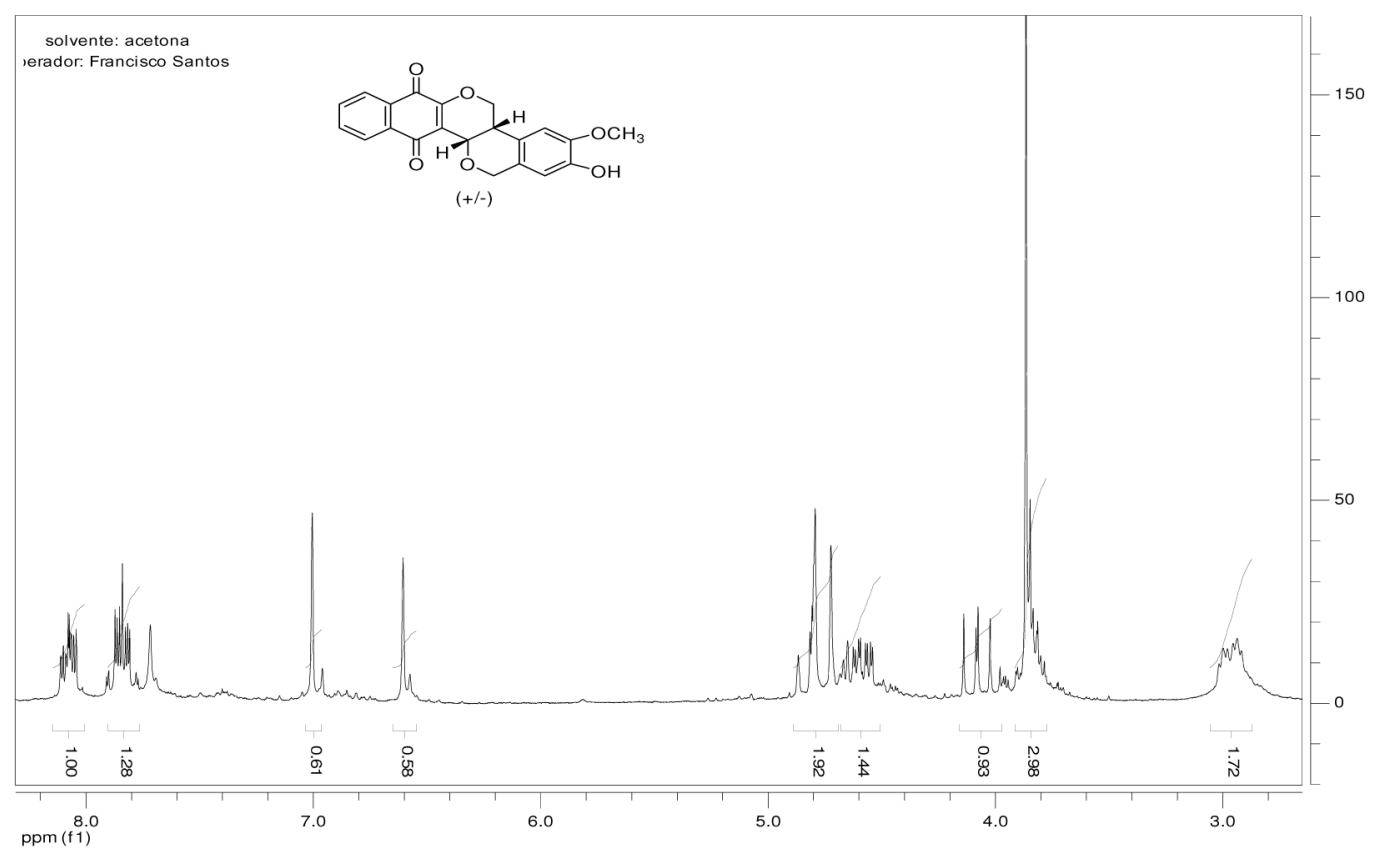

Figure S9. ${ }^{1} \mathrm{H}$ NMR spectrum for compound Mc. 
6

Antitumoral, Antileishmanial and Antimalarial Activity

J. Braz. Chem. Soc.

UNIVERSIDADE DO ESTADO DO RIO DE JANEIRO

Instituto de Química - Departamento de Química Orgânica
Grupo de Polímeros - GPol

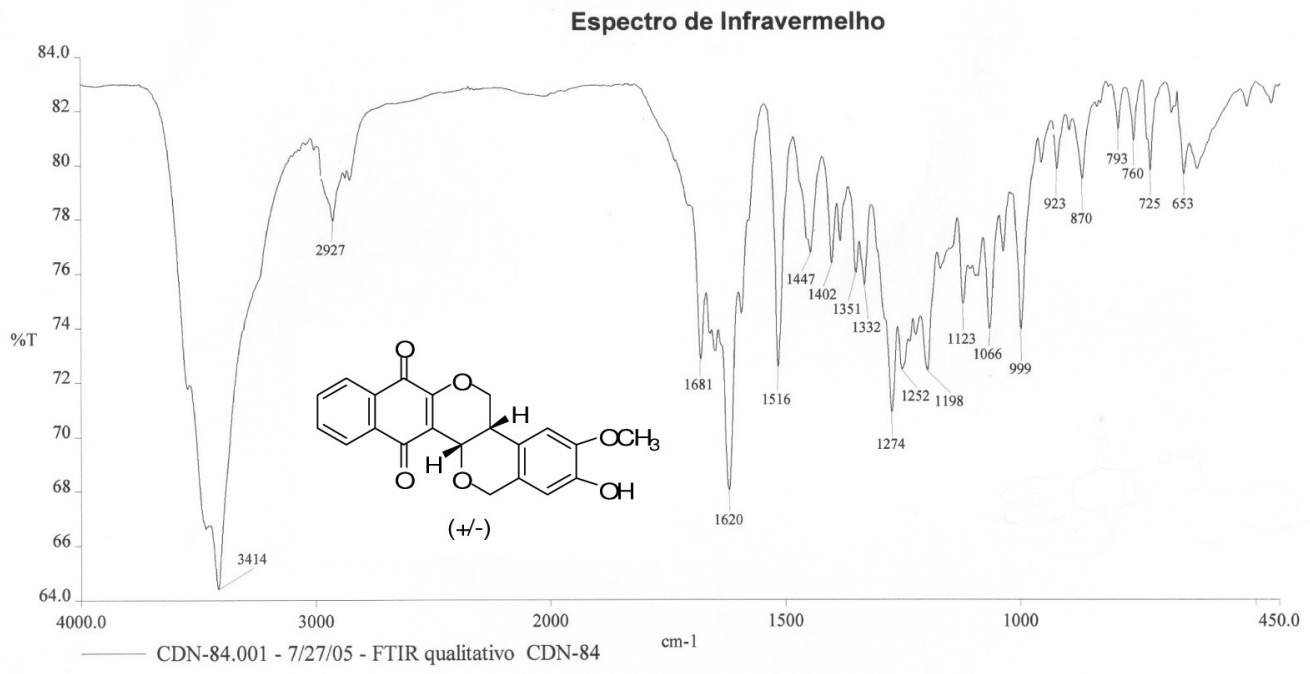

Figure S10. Infra Red spectrum for compound 9c. 